\title{
Prolegomena do badań nad decentralizacją administracji publicznej w sektorze rolnym na przykładzie procesu gospodarowania nieruchomościami rolnymi Skarbu Państwa
}

\section{Zagadnienia wprowadzające}

$\mathrm{Na}$ wstępie każdego opracowania, jak to powinno się czynić, rozpocznijmy od uwag metodologicznych oraz przybliżenia przedmiotu opracowania. Przedmiotem rozważań, na który pragniemy zwrócić uwagę, są procesy usamodzielniania się struktur państwowych w sektorze gospodarki państwową ziemią rolnąㄹ. W szczególności chodzi tu o poczynienie pewnej cząstkowej, współczesnej obserwacji, która zmierzać powinna w kierunku ustalenia narzędzi badawczych do lepszej oceny funkcjonowania już prawie 20-letniego procesu gospodarowania Zasobem Własności Rolnej Skarbu Państwa (w skr. Zasobem). Podniesienie tej tematyki w świetle najnowszej nowelizacji ustawy o gospodarowaniu nieruchomościami rolnymi skarbu Państwa staje się nie tylko potrzebne, ale i pilne.

Oczywiście opracowaniem niniejszym, ze względu na swoją formułę referatową, pragniemy jedynie sygnalizować kierunki dalszych badań problemu. Wydaje się, co antycypuje tytuł referatu, że dla lepszego efektu badawczego należy w pierwszej kolejności podejmować analizę regulacji ustrojowych dotyczących gospodarowania i nadzorowania państwową ziemią rolną. Przyjęcie bowiem określonej formuły organizacyjnej konkretnych struktur w danej dziedzinie administracji publicznej wskazuje już na określony typ lub znamiona samodzielności podmiotów ją wykonujących. W przypadku gospodarowania Zasobem od samego jego początku, a więc od początku lat dziewięćdziesiątych, nie było wątpliwości w doktrynie ani w jurysprudencji, że ten fragment gospodarki państwową gotowizną rolną poddany został

$1 \quad$ Uniwersytet Warszawski.

2 Dla uszczegółowienia, wyłączamy z rozważań państwową ziemię rolną będąca w innych zasobach państwowych, np. zawiadywaną przez starostów. 
regulacji szczególnej³. Charakteryzuje się ona daleko posuniętą odrębnością form organizacyjnych oraz metod działania.

Bardzo istotne będą również kwestie przyjęcia odpowiednich założeń metodologicznych. Należy wyraźnie podkreślić, że do zbadania wyżej wskazanego przedmiotu wykorzystanie jedynie metody formalno-dogmatycznej będzie zabiegiem koniecznym, aczkolwiek niewystarczającym. Do pełnej analizy potrzebne też będą w przyszłości ujęcia socjologiczne, historyczne i prawnoporównawcze, nie wyłączając metody statystycznej. Ze względu na istniejące już w literaturze opracowania częściowe ${ }^{4}$, a także zrozumiały upływ czasu i zmiany ustawowe, na użytek niniejszego opracowania wybieramy do analizy jedynie bardzo wąski wątek formalno-dogmatyczny ${ }^{5}$ dotyczący kwestii najnowszych zmian we wspominanej noweli ustawowej. Wydają się być one ustrojowo ważne dla jakości nadzoru nad Zasobem Własności Rolnej Skarbu Państwa.

\section{Ustalenia pojęciowe}

Kolejnym ważnym elementem w badaniu kwestii podstawowej, jaką jest zakładany proces usamodzielniania się czy też decentralizowania się państwowych struktur w sektorze rolnym, będą ustalenia pojęciowe. W szczególności chodzi tu o pojęcia administracji publicznej oraz decentralizacji w kontekście ustawy o gospodarowaniu nieruchomościami rolnymi.

$\mathrm{Na}$ pytanie, czy istnieje potrzeba wyodrębnienia struktur administracji rolnej i według jakich założeń mamy to czynić współcześnie, odpowiedzieć możemy jedynie poprzez odniesienie się do ogólnych ustaleń nauki. Analiza ta nie może więc odbiegać od dwóch podstawowych aspektów administracji publicznej (czy też jej rodzajów), przedmiotowego i podmiotowego ${ }^{6}$. Porównanie administracji publicznej w sensie przedmiotowym jest zadaniem ogromnym i prowadzić powinno właściwie poprzez porównanie licznych procedur administracyjnych w obrębie sektora rolnego na tle postępowań administracyjnych w innych dziedzinach administracyjnego prawa materialnego. Równie trudnym zadaniem, choć zakresowo węższym, jest porównanie administracji rolnej i innych administracji sektorowych na płaszczyźnie podmiotowej. Do takiego też kierunku badań zaliczyć pragniemy i niniejsze opracowanie. Podmiotowe podejście w charakterystyce struktur rolnych administracji publicznej uzasadnia ujmowanie w jednym zbiorze zarówno jednostki prywatnej,

Z ogólnych opracowań zob. M. Bednarek, Przemiany własności w Polsce. Podstawowe koncepcje i konstrukcje normatywne, Warszawa 1994, s. 92 i n.; S. Prutis (red.), Przekształcenia własnościowe w rolnictwie, Białystok 1996; J. Szachułowicz, Własność publiczna, Warszawa 2000; P. Czechowski, M. Możdżeń-Marcinkowski, Ewolucja własności rolniczej Skarbu Państwa, Studia luridica Agraria 2002, t. III.

$4 \quad$ Por. M. Możdżeń-Marcinkowski, Agencja Nieruchomości Rolnych, Kraków 2003 i literatura tam podana.

5 W większym stopniu formalny niż dogmatyczny ze względu na oczywisty brak orzecznictwa uwzględniający wchodzące w życie zmiany ustawowe.

6 Por. P. Czechowski (red.), Prawo rolne..., s. 115. 
jaką jest dom składowy, jak i Lasów Państwowych należących do jednostek państwowych. Dla potrzeb rozważań nad gospodarowaniem Zasobem równie istotnym elementem będzie ujęcie podmiotowe administracji rolnej. Interesujący w szczególności powinien być wpływ zmian ustawowych na prawną i faktyczną samodzielność Agencji Nieruchomości Rolnych oraz jej oddziałów terenowych w procesie obrotu Zasobem. W konsekwencji, w interesującym nas polu badawczym powinny pozostawać nie te regulacje, które dotyczą samej treści prawnej mechanizmów kontroli i nadzoru nad procesami gospodarowania Zasobem, lecz regulacje prawne odnoszące się do węższej kwestii, mianowicie do kompetencji i środków ustrojowych przynależnych innym organom publicznym w ramach nadzoru instancyjnego lub weryfikacyjnego nad Agencją, jako podmiotu wyposażonego w liczne zadania państwowe.

Następnym, niezbędnym ustaleniem będzie kwestia rozumienia pojęcia decentralizacji, a w konsekwencji określenie obrazu struktury zdecentralizowanej administracji rolnej. I tym razem niezbędne będzie kolejne zawężenie pola badawczego do pewnego tylko wycinka struktury rolnej administracji państwowej, do której zaliczyć należy niewątpliwie Agencję Nieruchomości Rolnych. Podmiot ten funkcjonuje równolegle ze zdecentralizowaną administracji rolną w ramach samorządu terytorialnego, licznymi samorządami zawodowymi rolników, związkami zawodowymi, stowarzyszeniami sektorowymi, nie wyłączając jednostek certyfikujących. Wszystkie wyżej wymienione podmioty budują w jakimś sensie strukturę zdecentralizowanej administracji rolnej.

Wracając do samego pojęcia decentralizacji, należy przypomnieć, iż jest ono pojęciem prawnym poprzez przepis art. $15 \mathrm{Konstytucji}^{7}$. Co ciekawe, wszelkie definicje tego pojęcia, gdyż jak to widzimy, w Konstytucji takiej nie odnajdziemy, mają już charakter prawniczy. Oparte są więc w głównej mierze na wypowiedziach doktryny, po części mamy też aspekt dogmatyczny ${ }^{8}$. Zwrócić należy również uwagę na to, że ustawodawca konstytucyjny, jak widać po konstrukcji art. 15, wypowiada się nie o decentralizacji administracji publicznej, lecz o decentralizacji władzy publicznej. Już sam ten fakt powoduje kontrowersje. W literaturze pojawiają się opinie, że decentralizacja władzy powinna być rozumiana także jako decentralizacja administracji publicznej9. W naszym przypadku kwestia ta ma jednak istotne znaczenie. W przypadku gospodarki Zasobem bowiem istotne jest, kto ma realną i rzeczywistą ,władzę” publiczną do kształtowania kierunków zagospodarowania i gospodarowania państwowymi nieruchomościami rolnymi. Będziemy próbowali pokazać, czy podział terytorialny państwa uwzględniający więzi społeczne, gospodarcze lub kulturowe i zapewniający jednostkom terytorialnym zdolność wykonywania zadań publicznych określa ustawa.

$8 \quad$ Z nowszej literatury por. S. Fundowicz, Decentralizacja administracji publicznej w Polsce, Lublin 2005.

$9 \quad$ Ibidem, s. 12. 
iż mimo wielu ograniczeń systemowych władzę tę dzierży głównie Agencja Nieruchomości Rolnych.

Wydaje się, że nawet pobieżna analiza ustawy o gospodarowaniu nieruchomościami rolnymi, zarówno w kontekście historycznym, jak i formalno-dogmatycznym nie pozostawia wątpliwości, że swoistym spiritus movens obrotu Zasobem jest sama Agencja Nieruchomości Rolnych. Dlatego tak istotną kwestią stają się środki nadzoru administracyjnego nad tą jednostką publiczną. Jak można łatwo zauważyć, art. 15 w ustępie drugim Konstytucji RP precyzuje rozumienie zasady decentralizacji jako tej, która odbywa się na poziomie podziału terytorialnego kraju. Wspólnoty samorządowe (gminne, powiatowe i wojewódzkie) są jednak w mniejszym stopniu niż władze centralne odpowiedzialne za koncesjonowanie i nadzór nad gospodarką rolną. Władzy terenowej pozostaje bowiem głównie władztwo planistyczne oraz wpływ na funkcjonowanie sołectw jako jednostek pomocniczych organów gminy ${ }^{10}$. Powracając do wątku głównego pytania o proces decentralizowania się Agencji jako jednostki publicznej, musimy określić, czym jest sama instytucja decentralizacji. Nie jest to instytucja prawna, choć samo pojecie, jak wspominano, pojawia się w prawie. Decentralizacja jest jedynie pewnym wykorzystywanym przez doktrynę, czasami przez judykaturę, pojęciem-narzędziem ${ }^{11}$. Pojęcia takie służą m.in. do opisywania zastanego, ustrojowego układu kompetencji materialno-ustrojowych danej jednostki publicznej. Zresztą nie tylko decentralizacja należy do pojęć-narzędzi, katalog taki ma oczywiście charakter stricte konwencjonalny, bowiem jest uzależniony od poszczególnych poglądów autorów. Możemy jednak do tego zbioru dodać również i samo pojęcie nadzoru, kontroli, kierownictwa itp. Odnosząc się już do samego rozumienia decentralizacji, definicja tego pojęcia uzyskała w polskiej literaturze koloryt po dziś dzień ukształtowany głównie dziełem Profesora Jerzego Starościaka, dedykowanego właśnie decentralizacji administracji publicznej ${ }^{12}$. Podążając za jego myślą, o istocie decentralizacji ma stanowić prawem określona samodzielność. Odróżnić więc tu należy samodzielność, a więc decentralizację prawną od decentralizacji faktycznej, a więc rzeczywistej swobody działania podmiotów podlegających kierownictwu. Profesor Starościak rozróżniał w związku z powyższym stronę bierną i czynną samodzielności jako określniki stopnia zdecentralizowania podmiotu ${ }^{13}$.

Na przykładzie sektora rolnego gospodarki decentralizacja władztwa publicznego w układzie podmiotowym jest rozwinięta na stosunkowo skromnym poziomie, choć liczba tych podmiotów rośnie. Charakteryzuje te podmioty różnorodny status prawny. Mowa tu zarówno o jednostkach centralnych, takich jak: KRUS, Lasy Pań-

10 Zob. opis samorządowej administracji rolnej, M. Możdżeń-Marcinkowski, P. Czechowski, P. Wojciechowski, Administracja rolna, (w:) P. Czechowski (red.), Prawo rolne, Warszawa 2011, s. 138 i n.

11 O pojęciach narzędziach zobacz szerzej: F. Longchamps, Uwagi o używaniu pojęć prawnych, ZNUWr. Prawo 1960 , z. 27, s.11 in.

12 J. Starościak, Decentralizacja administracji publicznej, Warszawa 1960, s. 16.

13 Ibidem, s. 10. 
stwowe, Polski Związek Działkowców, jak i terenowych: samorządy powszechne, np. administracja łowiectwa wykonywana przez samorząd województwa jako zadanie zlecone rządowe, jednostki doradztwa rolniczego - dawne ODR-y, samorządy zawodowe, izby rolnicze, społeczno-zawodowe organizacje rolników, częściowo związki zawodowe rolników, stowarzyszenia rolników oraz spółdzielnie rolnicze. Kolejną grupą podmiotów, ale już w rozumieniu przedmiotowym administracji publicznej, są przykładowo spółki do zagospodarowania wspólnot gruntowych, domy składowe, giełdy towarowe, grupy producentów rolnych, do pewnego stopnia też sami rolnicy w ramach obowiązków administracyjnoprawnych, a w szczególności w tych kompetencjach, w których państwo nakłada swoje obowiązki nieodpłatnie na obywatela ${ }^{14}$.

Podsumowując kwestię decentralizacji i użyteczności tego pojęcia w badaniu choćby statusu ustrojowego ANR, ale i innych podmiotów wskazanych wyżej, należy wskazać podstawowe cechy podmiotu zdecentralizowanego. Podmiot taki, co nie jest raczej kwestionowane w literaturze, ${ }^{15}$ powinien być względnie samodzielny (ale nie zdekoncentrowany i nie autonomiczny), utworzony ustawą, jego samodzielność zaś powinna być chroniona sądownie. Poza analizą pozostawiamy w tym miejscu problem samodzielności orzeczniczej organów rolnych jako elementu samodzielności prawnej, która również wydaje się mieścić w istocie decentralizacji ${ }^{16}$.

\section{Agencja Nieruchomości Rolnych a kwestia decentralizacji}

Jak już pisano, oprócz organów centralnych podległych, w strukturze występuje również pewien typ organów centralnych nadzorowanych przez Ministra Rolnictwa i Rozwoju Wsi ${ }^{17}$. Mowa tu o trzech państwowych agencjach rolnych: Agencji Nieruchomości Rolnych, Agencji Restrukturyzacji i Modernizacji Rolnictwa oraz Agencji Rynku Rolnego. Charakter ustrojowy agencji rolnych nie jest jednoznaczny. Wymienione wyżej agencje są, zgodnie z ich ustawami ustrojowymi (prócz Agencji Rynku Rolnego), państwowymi osobami prawnymi nadzorowanymi przez ministra rolnictwa i rozwoju wsi. Agencje te działają na podstawie ustaw i, w zasadzie, posiadają znaczny zakres samodzielności. Podążając za systematyką Profesora Starościaka, posiadają dużą samodzielność faktyczną. Nie są jednak administracją zdecentralizowaną, gdyż ich organy nie pochodzą z wyborów powszechnych, organy agencji są powoływane w drodze otwartego konkursu przez Prezesa Rady

Należy tu jednak zaznaczyć, że dystynkcja pomiędzy obowiązkiem obywatelskim nakładanym przez organ w procesie przyznawania pomocy publicznej a zdecentralizowanym zadaniem publicznym jest niezmiernie trudno uchwytna.

Por. M. Możdżeń-Marcinkowski, Wstęp do prawa administracyjnego ogólnego, wyd. 2, Warszawa 2009, w szczególności rozdział poświęcony zasadom prawa administracyjnego i literatura tam podana. 
Ministrów na wniosek Ministra Rolnictwa i Rozwoju Wsi. Z drugiej jednak strony organy agencji, wydając decyzje administracyjne (np. prezes KRUS, prezes ANR), korzystają z autonomii orzeczniczej i nie podlegają w tym zakresie poleceniom służbowym organów naczelnych. Charakterystycznym centralnym organem administracji rządowej jest prezes Kasy Rolniczego Ubezpieczenia Społecznego, powoływany i odwoływany przez Prezesa Rady Ministrów. Prezes KRUS wykonuje zadania nałożone ustawą z dnia 20 grudnia 1990 r. o ubezpieczeniu społecznym rolników ${ }^{18}$.

Agencja Nieruchomości Rolnych (ANR) powołana została ustawą o gospodarowaniu nieruchomościami rolnymi Skarbu Państwa (u.g.n.r.s.p.) z dnia 19 października 1991 r. ${ }^{19}$ pod nazwą Agencja Własności Rolnej Skarbu Państwa. Jej obecną nazwę zawdzięczamy ustawie o kształtowaniu ustroju rolnego z dnia 11 kwietnia 2003 r., ${ }^{20}$ która wprowadziła też dodatkowe zadania i kompetencje dla ANR. Agencja opisywana była w literaturze, w początkowych latach swojego funkcjonowania, jak i w aktualnych opracowaniach, jako jednostka o charakterze powierniczym ${ }^{21}$. Taka teza jednak po ponad 20-letnim okresie funkcjonowania na gruncie legislacyjnym nie wytrzymuje próby czasu. Zmiany ustawodawcze dotyczące statusu Agencji i Zasobu Własności Rolnej nie poszły w kierunku systemowych regulacji powierniczych. Obecny kształt Agencji i zespołu jej kompetencji wobec Zasobu pokazuje, iż nie różni się ona zasadniczo od poszczególnych centralnych organów administracji rządowej w kwestii ustrojowej. Zakładany początkowo przez naukę i jurysprudencję „powierniczy” charakter Agencji pozostaje koncepcją właściwie teoretyczną. Użyte w ustępie 1 art. 5 u.g.n.r.s.p. sformułowanie, iż Skarb Państwa powierza Agencji wykonywanie prawa własności i innych praw rzeczowych na jego rzecz w stosunku do określonego mienia, nie daje podstawy do postawienia tezy o powstaniu odrębnej, ustawowej instytucji powiernictwa państwowego. Również prezes ANR nie posiada statusu organu regulacyjnego, a jego powoływanie i odwoływanie jest każdorazowo związane ze zmianami kolejnych gabinetów rządowych. Nie pozwala to na budowanie długofalowej polityki zagospodarowania Zasobu, choć z drugiej strony Agencja ma właściwie nieograniczoną swobodę profilowania bieżącej gospodarki gruntami w ramach instrumentów ustawowych. Wydaje się również, iż element sądowej ochrony prawnej Agencji, jako element istotowy decentralizacji, wydaje się w funkcjonowaniu tej jednostki zachowany. Swoboda działania Agencji jest przecież chroniona sądownie w ramach ochrony posesoryjnej i windykacyjnej w trakcie realizacji normy art. 5 u.g.n.r.s.p., a więc wykonywania prawa własności i innych praw rzeczowych. $Z$ drugiej strony prezesowi Agencji wydawane są niekiedy polecenia służbowe przez organy naczelne, które to działania właściwie w tym aspek-

18 Tekst jedn. Dz.U. z 2008 r. Nr.50, poz. 291.

19 Tekst jedn. Dz.U. z 2007r. Nr 231, poz. 1700 z późn. zm.

20 Dz.U. Nr 64, poz. 592 z późn. zm.

21 Por. M. Możdżeń-Marcinkowski, Agencja Nieruchomości Rolnych, Kraków 2003, s. 38 i n. oraz literatura tam powołana. 
cie znacznie pomniejszają samodzielność Agencji jako odrębnej państwowej osoby prawnej, a więc redukują aspekt decentralizacji prawnej. Po prostu pomijany jest tu przez rząd aspekt odrębności osobowości prawnej Agencji. Do elementów redukujących decentralizację prawną zaliczyć należy również sytuację, w której Agencja nie może w pełni swobodnie dysponować środkami pochodzącymi z gospodarowania Zasobem Własności Rolnej Skarbu Państwa. Potwierdza to obligatoryjny mechanizm wpłaty części dochodów do budżetu państwa, a także obowiązek finansowania kosztów innych ustaw ${ }^{22}$. Jej budżet w sposób semiimperatywny ustalany jest przez Radę Ministrów i Ministra Finansów przy udziale Ministra Rolnictwa i Rozwoju Wsi. Lista zadań ANR jest wciąż poszerzana przez kolejne ustawy. Samodzielność budżetowa jest kluczowym elementem samodzielności i faktycznej, i prawnej.

Reasumując, można dziś już mówić o zatarciu funkcji powierniczej ANR i skomplikowanej szachownicy kompetencji, które formalnie pozycjonują tę instytucję poza katalogiem jednostek zdecentralizowanych, jednak w sensie materialnym pozostawiającym tej jednostce wciąż ogromną swobodę działania. Jak już wspominano, Agencja, z punktu widzenia obecnych funkcji, zadań i pozycji ustrojowej jest $\mathrm{w}$ istocie centralnym organem administracji rządowej pod nazwą „Agencja Nieruchomości Rolnych"23. Na pytanie, czy Agencja Nieruchomości Rolnych jest podmiotem zdecentralizowanym, nie możemy odpowiedzieć twierdząco choćby z powodów ustrojowych. Chodzi tu też, obok aspektów podawanych wyżej, o pewną przeszkodę w regulacji ustrojowej, w której organ prezesa tej Agencji jest ewidentnie powoływany i odwoływany przez Prezesa Rady Ministrów na wniosek Ministra Właściwego do Spraw Rolnictwa. W tym sensie prezes Agencji podlega zależności osobowej, która jest fundamentem podległości służbowej ${ }^{24}$.

Jednak ostatnie zmiany w ustawie wydają się podwyższać stopień decentralizacji prawnej. Mowa tu o nowelizacji, która weszła w życie 3 grudnia 2011 roku $^{25}$. Przypomnieć dla porządku należy, że nowela ta jest realizacją jedynie jednej z trzech koncepcji zmian w obrocie Zasobem Własności Rolnej Skarbu Państwa. W zeszłej kadencji sejmu były jeszcze dwa projekty (poselski i komisyjny; druki: 2819 i 1423). Należy więc obawiać się, że zmiany w ustawie wprowadzone przez obecną koalicję rządową będą poddawane dalszej krytyce, a w konsekwencji sprzyjać to może niestabilności założeń polityki Zasobem. W tak ważnej sprawie jak obrót ziemią państwową rząd powinien wciąż dążyć do jak najszerszego konsensusu politycznego, szerszego niż jedynie koalicyjnego.

22

Np. udział w finansowaniu rekompensat za utracone mienie zabużańskie.

Zob. P. Czechowski, op. cit., s. 126.

„Prezesa Agencji powołuje Prezes Rady Ministrów, na wniosek ministra właściwego do spraw rozwoju wsi, spośród osób wyłonionych w drodze otwartego i konkurencyjnego naboru. Prezes Rady Ministrów odwołuje Prezesa Agencji”, art. 9, ust. 1. Ustawy o gospodarowaniu nieruchomościami rolnymi Skarbu Państwa, op. cit., przyp.19. Ustawa z dnia 16 września 2011 r. o zmianie ustawy o gospodarowaniu nieruchomościami rolnymi Skarbu Państwa oraz o zmianie niektórych innych ustaw, Dz.U. Nr 233, poz. 1382. 
Szczegółowa analiza noweli ustawy, szczególnie prześledzenie całego jawnego, sejmowego procesu jej tworzenia jednoznacznie wskazuje, że w pierwszej kolejności realizowany nią będzie cel fiskalny. Głównym mechanizmem służącym temu celowi jest zapisanie w katalogu sposobów gospodarowania Zasobem dyrektywy ustawowej w art. 24 ust. 1 wprost nakazującej Agencji w pierwszej kolejności sprzedawać. Ustawodawca niestety nie wychodzi naprzeciw, od dawna już podnoszonym w nauce prawa i zarządzania wątpliwościom, czy preferowana przez rząd i Agencję metoda uzyskania najwyższej ceny (a czasami jakiejkolwiek ceny) za grunt jest jedyną i najlepszą formą wykorzystania państwowych gruntów rolnych. Co jest bardziej korzystne, maksymalizacja wpływów ze sprzedaży od nabywców gruntów, czy też może zmiana myślenia w kierunku szerokiego i taniego udostępniania tych gruntów polskim rolnikom i skupienie się następnie na egzekwowaniu podatków i innych obowiązków administracyjnoprawnych? Co jest zatem korzystniejsze: bogatsze państwo czy bogatszy obywatel-rolnik? Niestety, ustawodawca wciąż pozostaje głuchy na postulaty nauki i praktyki w sprawie generalnego przemodelowania zasad obrotu państwowymi gruntami rolnymi w kierunku przekształcenia Agencji w instytucję pomagającą $\mathrm{w}$ kompleksowym procesie aktywnego wspierania rodzinnych gospodarstw farmerskich, poprzez prawdziwy, tzn. wsparty szerokimi i łatwo dostępnymi kredytami, program osadnictwa młodych rolników na gruntach państwowych; upełnorolnienia dotychczasowych gospodarstw, a także włączenia Agencji Nieruchomości Rolnych jako aktywnego podmiotu w ramach Programu Rozwoju Obszarów Wiejskich $^{26}$.

Ustawodawca zlikwidował nowelą także jeden z organów Agencji, jakim była Rada Nadzorcza, pozostawiając Prezesa jako jedyny organ Agencji. Dla przypomnienia, dotychczasowa Rada Nadzorcza była pewnym eksperymentem, być może niezbyt udanym, jednak łączącym elementy nadzoru zewnętrznego i stałego nadzoru wewnętrznego nad organem wykonawczym, jakim jest prezes Agencji. Rada ta miała wąskie kompetencje, ale stanowiła jednak element nadzoru stałego. Rada składała się z przewodniczącego i jedenastu członków, w tym:

1) trzech przedstawicieli ministra właściwego do spraw rozwoju wsi;

2) trzech przedstawicieli ministra właściwego do spraw Skarbu Państwa;

3) po jednym przedstawicielu ministra właściwego do spraw finansów publicznych oraz ministra właściwego do spraw gospodarki;

3a) jednego przedstawiciela Krajowej Rady Izb Rolniczych; dżeń-Marcinkowski, Agencja Nieruchomości Rolnych - przyszłe kierunki przekształceń, „Studia luridica Agraria” 2007, t. 6 . 
4) trzech przedstawicieli powoływanych spośród kandydatów zgłoszonych przez związki zawodowe rolników, organizacje społeczno-zawodowe rolników, związki zawodowe pracowników rolnictwa, rolnicze związki spółdzielcze, związki dzierżawców, administratorów i właścicieli nieruchomości rolnych oraz organizacje pracodawców rolnych - o zasięgu krajowym.

Jak już podkreślano, sam skład Rady i jej nieliczne kompetencje stanowiły jednak element stałego nadzoru nad działaniami Prezesa ANR. Należy wyraźnie podkreślić, że obecny stan prawny daje Ministrowi Rolnictwa i Rozwoju Wsi właściwie niewielkie, bezpośrednie środki tzw. stałego nadzoru, np. poprzez merytoryczną ingerencję w bieżące gospodarowanie mieniem Zasobu przez Agencję. Znosząc Radę Nadzorczą, nowelizacja nie określiła zarazem nowego katalogu środków merytorycznego nadzoru dla Ministra. Jeżeli przypomnimy, że Agencja jest wyodrębnioną państwową osobą prawną i nie podlega Ministrowi, a jedynie ustawie, to czyni z prezesa Agencji, pomimo wskazywanych wyżej, innych systemowych ograniczeń, organ sui generis zdecentralizowany. Jedynym instrumentem nadzorczym ministra pozostaje wciąż, i jedynie, środek prawny ad personam, tj. odwołanie Prezesa Agencji. Pozostaje tez Ministrowi wnoszenie kolejnych, czasochłonnych, inicjatyw ustawodawczych.

Ustawodawca, pomimo próśb wielu środowisk, wciąż nie określił wewnętrznej polityki rolnej państwa dotyczącej nieruchomości państwowych. Jeżeli zestawimy to ze wspominaną powyżej fiskalną dyrektywą ustawową sprzedaży, to łatwo możemy zauważyć, iż coraz szybciej uszczuplany Zasób Własności Rolnej w niedługim czasie nie będzie mógł już służyć np. do celów wciąż nierozwiązanej kwestii reprywatyzacji zabranej przez PRL bez odszkodowania własności prywatnej. W nowelizacji ustawodawca postanowił też dać Agencji prawo do ingerencji w przyszłe umowy dzierżawne oraz co najbardziej kontrowersyjne, w już podpisane i obowiązujące umowy dzierżawy. W znowelizowanej ustawie w art. 38 dodaje się ust. 1a, zgodnie z którym „W umowie dzierżawy, także zawieranej na czas oznaczony, zawiera się postanowienie o możliwości wypowiedzenia przez agencję umowy dzierżawy w zakresie wyłączenia $30 \%$ powierzchni użytków rolnych będących przedmiotem dzierżawy." W przypadku już podpisanych umów Agencja w ciągu 6 miesięcy, począwszy od 3 grudnia tego roku, przesyłać będzie zawiadomienia i propozycje zmian w umowach. Oznacza to istotną ingerencję w prawa dotychczasowych dzierżawców. Nadmienić należy, że konstrukcja ta była krytykowana przez zewnętrzne opinie eksperckie jako niekonstytucyjna. O tym, czy takie obawy są zasadne, może oczywiście skutecznie orzec jedynie Trybunał Konstytucyjny, jednak już na tym etapie okiem laika widać, że dzierżawca jest podmiotem podrzędnym w tej relacji. Ustawodawca zastosował tu bowiem pewną sankcję. Odrzucenie oferty Agencji o zabraniu dzierżawcy $30 \%$ powierzchni dzierżawy skutkować będzie w przyszłości brakiem możliwości skorzystania z prawa pierwszeństwa nabycia dotychczas dzier- 
żawionych gruntów państwowych, nie będzie też mógł on skorzystać jako dotychczasowy dzierżawca $\mathrm{z}$ trybu bezprzetargowego.

Ustawodawca w komentowanej nowelizacji postanowił również dokonać zmian $\mathrm{w}$ innej ustawie o kształtowania ustroju rolnego. Zmiany w tej ustawie są na tyle istotne, że zasługują na odrębne opracowanie, jednak pokrótce należy ocenić je jako wprowadzające jednak pewien „chaos” w dotychczasowych pojęciach. Przykładowo wprowadza się zmiany w definiowaniu pojęcia rolnika indywidualnego. Nowela powoduje więc, że mnożą nam się kategorie rolnika indywidualnego. Powoduje to, że w jednej wsi pod rządami tej samej ustawy będą 3 kategorie rolników indywidualnych. W związku z tym dla obecnych i przyszłych nabywców gruntów rolnych nowelizacja oznacza obowiązek dokształcania się w okresie lat 5 od momentu wejścia ustawy w życie oraz - co najważniejsze - obowiązek zamieszkiwania od 5 lat $\mathrm{w}$ gminie, na obszarze której jest położona jedna z nieruchomości rolnych wchodzących w skład gospodarstwa rolnego i prowadzenie przez ten okres osobiście tego gospodarstwa.

Do tej pory wystarczał wymóg zamieszkania nieokreślony czasowo - w praktyce można było zameldować się tuż przed transakcją, aby skorzystać ze statusu rolnika indywidualnego.

Nowelizacja kończy również z liberalnym podejściem do kwestii kwalifikacji rolniczych. Następuje powrót do znanego z czasów sprzed 1989 roku zacieśniania przesłanek uprawniających do nabycia gruntów rolnych. Nie wystarczy już do statusu rolnika indywidualnego, aby jakakolwiek osoba uzyskała wykształcenie rolnicze co najmniej zasadnicze lub wykształcenie średnie lub wyższe (jakiekolwiek), lub osobiście prowadziła gospodarstwo rolne, lub pracowała w gospodarstwie rolnym przez okres co najmniej 5 lat. Po nowelizacji, z uwzględnieniem wspominanego 5-cioletniego okresu dostosowawczego, osoba posiada kwalifikacje rolnicze, jeżeli uzyskała:

a) wykształcenie rolnicze zasadnicze zawodowe, średnie lub wyższe lub

b) tytuł kwalifikacyjny lub tytuł zawodowy, lub tytuł zawodowy mistrza w zawodzie przydatnym do prowadzenia działalności rolniczej i posiada co najmniej 3-letni staż pracy w rolnictwie, lub

c) wykształcenie wyższe inne niż rolnicze i posiada co najmniej 3-letni staż pracy w rolnictwie albo wykształcenie wyższe inne niż rolnicze i ukończone studia podyplomowe w zakresie związanym z rolnictwem, albo wykształcenie średnie inne niż rolnicze i posiada co najmniej 3-letni staż pracy w rolnictwie, lub

d) wykształcenie podstawowe, gimnazjalne lub zasadnicze zawodowe inne niż rolnicze i posiada co najmniej 5-letni staż pracy w rolnictwie. 
Prolegomena do badań nad decentralizacja administracji publicznej w sektorze rolnym...

Za staż pracy, o którym mowa w ust. 2, uznaje się okres, w którym osoba fizyczna:

1) podlegała ubezpieczeniu społecznemu rolników lub

2) prowadziła działalność rolniczą w gospodarstwie rolnym o obszarze nie mniejszym niż 1 ha stanowiącym jej własność, przedmiot użytkowania wieczystego, przedmiot samoistnego posiadania lub dzierżawy, lub

3) była zatrudniona w gospodarstwie rolnym na podstawie umowy o pracę lub spółdzielczej umowy o pracę, wykonując pracę związaną z prowadzeniem działalności rolniczej, lub

4) wykonywała pracę związaną z prowadzeniem działalności rolniczej w charakterze członka spółdzielni produkcji rolnej, lub

5) odbyła staż, o którym mowa w art. 53 ust. 1 ustawy z dnia 20 kwietnia 2004 r. o promocji zatrudnienia i instytucjach rynku pracy (Dz.U. z 2008 r. $\mathrm{Nr}$ 69, poz. 415 z późn. zm.), obejmujący wykonywanie czynności związanych z prowadzeniem działalności rolniczej

Są też jednak i pozytywne uregulowania w nowym prawie. Ustawodawca wprowadził bowiem cenne ułatwienia dla właścicieli gruntów, które sąsiadują z gruntami Zasobu w ich nabyciu. Dodano w art. 29 ustawy ustęp 1h, zgodnie z którym nieruchomość Zasobu lub jej część może być sprzedana bez przetargu, jeżeli może poprawić warunki zagospodarowania nieruchomości przyległej stanowiącej własność osoby chcącej nabyć tę nieruchomość lub jej część, o ile nieruchomość ta nie może być zagospodarowana samodzielnie. Ustawodawca w przypadku spłaty należności za nabywane grunty obniżył też tzw. „dolną” wpłatę z 20\% do $10 \%$ i pozostawił możliwość rozłożenie pozostałej sumy na okres 15 lat.

\section{Wnioski}

Pobieżny ogląd statusu Agencji w świetle zasady decentralizacji nie daje zadawalających efektów analizy. Szereg wskazywanych wyżej kompetencji wskazuje na wciąż eklektyczny charakter prawny tej jednostki publicznej. Wynikiem ustrojowej analizy badanego podmiotu publicznego, jakim jest Agencja, powinien być jasny dla czytelnika obraz układu struktur nadzorujących oraz ich kompetencji na każdym etapie gospodarowania przez nią Zasobem. Chodzi tu nie tylko o kontrolę i nadzór państwowy, ale także kontrolę publiczną (w rozumieniu wpływu samorządów terytorialnych) oraz kontrolę społeczną w rozumieniu publicznych praw podmiotowych zwykłego obywatela. Jeżeli przykładowo Agencja decyduje się na sprzedaż nieruchomości lub innego mienia, w danym terenie o danym znaczeniu lokalnym i społecznym, to interesować nas powinno, jaki wpływ na tę decyzję mają odpowiednie ciała publiczne. Chodzi tu np. o: komisje i podkomisje sejmowe, władze samorzą- 
dowe, ministra rolnictwa i rozwoju wsi czy też związki zawodowe, nie mówiąc już o społeczności podstawowej, jaką są lokalni rolnicy i inni producenci rolni pracujący i żyjący w miejscu pozostającym w jurysdykcji danego oddziału terenowego Agencji. Lektura tekstu ustawy, jak również prześledzenie orzecznictwa pokazuje, że środki kontrolno-nadzorcze, czy też jakikolwiek bezpośredni wpływ wyżej wskazanych podmiotów na politykę Agencji są stosunkowo niewielkie. Prostym testem sprawdzającym publiczne prawo podmiotowe obywatela czy też podmiotu gospodarczego $\mathrm{w}$ procesie gospodarowania mieniem publicznym, upraszczając prawo obywatela do wpływu na losy tego mienia, jest pokazanie jakiegokolwiek skutecznego uprawnienia przeciwdziałającego, opartego na ustawie. Otóż w przypadku gospodarowania nieruchomościami przez Agencję u.g.n.r.s.p. nie daje bezpośrednio żadnych mechanizmów kontroli tego obrotu obywatelom. Jaki bowiem mają wpływ lokalni rolnicy na rozpoczęcie procedury sprzedaży danych gruntów z Zasobu. Być może jedynym postępowaniem, którym moglibyśmy się tu posiłkować, jest postępowanie w sprawach skarg i wniosków przewidziane w kodeksie postępowania administracyjnego, ale tam przedmiotem postępowania nie jest sprawa administracyjna, lecz sprawa skargowa. Przedmiotem badania skargi na działania Agencji będzie tu skarga na proces załatwiania sprawy obywatela, a nie na samą treść tej sprawy. W nieco lepszej sytuacji są władze samorządowe, które co prawda bezpośrednio nie mogą ingerować $\mathrm{w}$ proces gospodarowania, lecz pośrednio, poprzez władzę planistyczną znacząco mogą taką politykę kształtować. Stosunkowo słabą pozycję posiada także minister rolnictwa i rozwoju wsi, który posiada właściwie dwie możliwości wpływu na działalność Agencji. Pierwsza jest czasochłonna, bo związana z procesem legislacyjnym (wydawanie wiążących Agencję rozporządzeń i poddawanie Radzie Ministrów pod rozwagę projektów ustaw lub zmian ustawowych). Druga możliwość ministerialna to środki nadzorcze ad personam w stosunku do prezesa Agencji, a więc możliwość odwołania i powołania nowego. Historycznie istniała jeszcze trzecia ścieżka nadzorcza, ale z dniem 3 grudnia 2011 roku została zniesiona. Mowa tu o Radzie Nadzorczej Agencji, która wykonywała stały nadzór nad gospodarowaniem Zasobu.

W kontekście badania stopnia decentralizacji Agencji rodzi się więc pytanie, kto tworzy realnie politykę gospodarowania Zasobem. Odpowiedź jest z jednej strony trudna, z drugiej dość oczywista, tworzy ją w ogromnym stopniu sama Agencja w trudnym, jak próbowano pokazać, również dla niej samej układzie systemowych ograniczeń. Skoro zaś jedynym organem Agencji, po nowelizacji, pozostaje prezes Agencji, istotnym będzie podkreślenie, że aktualną politykę zagospodarowania Zasobem tworzy, w oparciu o ustawowe kompetencje i z uwzględnieniem czynników polityczno-ustrojowych, zawsze prezes Agencji.

Oczywiście naiwnością byłoby sądzić, iż prezes Agencji działa w próżni politycznej. Tak głębokiego stopnia decentralizacji nie możemy oczekiwać w naszych 
uwarunkowaniach społecznych. Ogromny, choć formalnie jedynie pośredni wpływ na zagospodarowanie Zasobu mają kwestie przynależności do partii politycznej zarówno prezesa Agencji oraz - co najważniejsze - Ministra Rolnictwa i Rozwoju Wsi. Jeżeli obydwaj piastunowie wymienionych organów przynależą do jednej partii, to znaczący wpływ na zagospodarowanie Zasobu mają, w sposób nieformalny, władze określonej partii politycznej. Sprawa komplikuje się w przypadku reprezentowania przez prezesa Agencji i ministra rolnictwa dwóch odmiennych stronnictw politycznych. W takim układzie dochodzi do oddziaływania na politykę zagospodarowania Zasobu dwóch frakcji, co w konsekwencji zazwyczaj spowalnia procesy zagospodarowania $^{27}$ lub przyspiesza te procesy ${ }^{28}$.

27 Przykładem może być polecenie służbowe premiera Jerzego Buzka, które obowiazzwało do 2011 roku w sprawie wstrzymania sprzedaży mienia objętego roszczeniami byłych właścicieli, por. M. Możdżeń-Marcinkowski, Agencja..., s. 104. 


\title{
Prolegomena to the study of decentralization within public administration in the agriculture sector on the example of the management of the State Treasury
}

\begin{abstract}
Key words: state public body, Agricultural Property Agency, government agency

The subject of discussion in this article are the processes of progressive emancipation of state public bodies(organs) in the agricultural economy. In particular, we show that it is necessary to make a partial contemporary observation, which should strive towards establishing a better research tools to study the functioning of government agencies in the agricultural sector. After a nearly 20 -year period of the legal mechanisms for the management of state agricultural property there is a need to summarize the state policy in this sector.Choosing this theme, in light of recent amendments to the Law on Management of State Treasury agricultural property is not only necessary but urgent.
\end{abstract}

